\title{
DERIVATIVES USAGE BY NON-FINANCIAL FIRMS IN EMERGING MARKETS: THE PERUVIAN CASE
}

\author{
USO DE LOS DERIVADOS FINANCIEROS POR FIRMAS \\ NO FINANCIERAS EN LOS MERCADOS EMERGENTES: \\ EL CASO PERUANO
}

\author{
Miguel Ángel Martin ${ }^{1}$, Wolfgang Rojas, José Luis Eráusquin, \\ Dayana Yupanqui y Édgar Vera
}

\begin{abstract}
Financial derivatives markets have reached a remarkable development in recent years, but this pattern has not attained the same strength in developing countries. In consequence, an important question arises: what is the development degree of financial derivatives markets in emerging countries and which variables influence the use of derivatives in the top companies? To analyze this topic, Peru has been chosen as a reference and the Non-Financial Firms as well. In order to enhance objectivity, an empirical study has been conducted through a structured survey directed to chief financial managers of companies classified among the TOP 1000 in the country. This information was collected in order to explain the effect of the determinants that influence the development of financial derivatives in Peru. The results show that the use of derivatives in Peru is low and the relevant factors affecting its development are the degree of training in derivatives and the market regulation. This outcome suggests that there should be patterns of behaviour for market agents and government entities to promote the use of derivatives, as well as provide information for future research that might contribute to establish the most adequate mechanisms for market-development purposes.
\end{abstract}

Keywords: Derivative markets, derivative usage, regulation, accounting, risk management, emerging markets.

\section{RESUMEN}

Los mercados de derivados financieros han alcanzado un desarrollo significativo en años recientes, pero este patrón no ha logrado la misma fuerza en los países en desarrollo. En consecuencia, una pregunta importante surge: ¿cuál es el grado de desarrollo de los mercados de derivados financieros en los países emergentes, y qué variables influyen en el uso de derivados en compañías importantes? Para analizar este tema se ha tomado como referencia al Perú así como a las firmas no financieras. Para optimizar la objetividad, se ha realizado un estudio empírico a través de una encuesta estructurada dirigida a los gerentes financieros de compañías incluidas dentro de las TOP 1000 del país. Esta información se recogió para explicar el efecto de los determinantes que influencian el desarrollo de los derivados financieros en el Perú. Los resultados muestran que la aplicación de estos derivados en el país es baja y que los factores relevantes que afectan su desarrollo son el grado de entrenamiento en derivados y la regulación del mercado. Este resultado sugiere que deberían existir patrones de conducta entre los agentes de mercado y las entidades gubernamentales para promover el uso de derivados, así como proveer información para investigaciones futuras que contribuyan a establecer los mecanismos adecuados con el propósito del desarrollo del mercado

Palabras claves: Mercados de derivados, uso de derivados, regulación, contabilidad, gestión de riesgo, mercados emergentes.

1. Universidad ESAN (Perú). Ph. D. in Economics and Business Sciences with specialization in Risk Management and Derivative Markets, UNED, Spain.<mmartin@esan.edu.pe >. 


\section{INTRODUCTION}

Due to the existing high volatile exchange rates and interest rates in developing countries, it is appropriate to use derivatives as an instrument of hedging. Moreover, hedging of exchange rates volatility turns more important for economies such as the Peruvian and other Latin American countries with a predominant financial dollarization.

As the first step to explore the degree and type of hedging by non-financial firms in Peru, the research focused on the use of interest rate and currency derivatives, as well as in the variables that would affect their development. The primary objectives were to determine the level of financial derivatives use in a representative sample comprised from the Peruvian TOP 1000 firms, and, based on this information, to identify the reasons that encourage businesses to use, or not, financial derivatives to minimize risk exposure. This would provide information about the importance organizations grant to risk factor, and what they implement to manage it.

This survey is the first of its kind in Peru, and it is the result of some modifications on the Wharton School survey, a study about derivatives used by non-financial corporations in the United States since 1994 (Bodnar \& et al., 1995, 1996, 1998). The advantage of applying this survey is that provides a pattern that allows international comparison. In addition to typical statistical and descriptive information, other analytical techniques were used to investigate factors that affect the use of financial derivatives.

The research collected formal information from non-financial firms in order to identify relevant factors related to the handling of derivatives. These factors will form the basis for strategic decisions aimed to encourage and improve the use of these financial instruments in Latin American economies.

The empirical results of this paper show that only $33 \%$ of non-financial firms among the Peruvian TOP 1000 deal with derivatives, and allow identification of two main factors for their use. The first factor is the degree of market knowledge and training level on finan- cial instruments; the second is regarding regulations influence (tax, legal and accounting issues) about the use of financial derivatives. Indeed, these results indicate that any strategy taken to develop the derivatives market must necessarily include diffusion of information about the use of these instruments, training initiatives at private level, and offer projects which complement the current laws in order to clarify the related legal treatment.

Additionally, it has been found that a great number of firms that use derivatives and whose chief financial managers stated to be familiar with derivatives did not show any knowledge about market topics and functional activities of derivatives. This result proves that it is not enough to have a basic understanding of financial derivatives functioning to promote the development of the derivatives market; at least not until initial actions to circulate the appropriate information would be taken.

\section{PREVIOUS STUDIES}

There are studies that use market and financial statement data to analyse the use of derivatives in non-financial firms. For instance, Mian (1996) presents empirical evidence of the determinants that influence the corporate hedging policy, using a sample of 3.022 firms. He classifies firms into 771 hedgers and 2,251 non-hedgers using 1992 annual financial statements (a $25.5 \%$ utilization rate). Nance, Smith, \& Smithson (1993) investigated the hedging activities of 169 firms among the Fortune 500 and S\&P 400, and found that 104 corporations used hedging instruments in that fiscal year. Their results indicate that firm hedging decisions are related to the investment tax credit, but they are unrelated to financial distress and agency costs. Furthermore, Geczy, Minton and Schrand (1997) investigated 372 of the Fortune 500 non-financial firms that had potential exposure to foreign currency risk. Based on 1991 financial statements, the authors found a $41.4 \%$ usage rate of derivatives.

Different studies employed survey data. For instance, Block \& Gallagher (1986) determined that the handling of derivatives by non-financial firms was made through forwards, futures, options and swaps. 
Their main conclusion was that larger organizations used interest derivatives more extensively than smaller firms. Among other studies, there are the surveys of the Treasury Management Association (1996). There are specially three studies based on large-scale surveys conducted by specialists of the Wharton School: one in 1994, published by Bodnar, Hayt, Marston, \& Smithson in 1995; the second one conducted in 1995 and published by Bodnar, Hayt, \& Marston in 1996; and the last one in 1998, again published by Bodnar, Hayt \& Marston in 1998.

With the same purpose, there have also been studies based on the Wharton School surveys about the handling of derivatives by non-US companies. Berkman \& Bradbury (1996) carried out a similar study with a sample of 116 firms listed on the New Zealand Stock Exchange. They found that the use of derivatives rises with leverage, company size, tax losses, and the proportion of shares held by managers. However, it decreases with the increase of interest coverage and liquidity. Later, Prevost, Rose, \& Miller (2000) extended those investigations to New Zealand firms resulting in an increase of the use of derivatives following the same pattern of the largest American and European companies.

The Wharton School survey was also employed in studies about derivatives' use in Japan (Yanagida \& Inui, 1995), Canada (Downie, McMillan, \& Nosal, 1996), Sweden (Alkeback \& Hagelin, 1999), and Australia (Nguyen $\&$ Faff, 2002). The main reason for using derivatives is for minimizing volatility in cash flow as well as risk coverage due to the decrease of loss probability. Berkman and et al. (1997), Joseph and Hewins (1997), and Bodnar and Gebhardt (1998) have found similar results in New Zealand, England and Germany, respectively.

However, there are few studies on the same subject in emerging countries, such as the case of Latin America. Rivas-Chavez (2003) shows the remarkable use of derivatives by financial firms in Brazil, Chile and Mexico. One of the most important conclusions is that Latin American banks do not offer derivatives in order to minimize interest rate and credit risk. It is also remarkable that the derivatives usage is not related to the efficiency of such banks.

\section{EMPIRICAL STUDIES}

\section{Population and sample size}

In Latin America, financial derivatives transactions are concentrated in Argentina, Brazil, Chile, and Mexico. These are countries with organized markets, compared to the rest of Latin American countries where financial activity is small. Peru was chosen to conduct the investigation of financial derivatives usage in emerging countries. This is a country where there is no organized derivatives market, and lacks of the legal and tax regulation framework. Many other Latin American countries present similar financial circumstances.

This study was based upon information from Peruvian corporations included in the list of "TOP 1000" companies, a ranking of the 1000 largest private companies measured by their gross revenues. This ranking is performed yearly by Gerens School of Management and Economics. They represent $70 \%$ of the Peruvian GDP, and they can be considered among the main promoters of the country's financial market. In recent years, the traded volume of financial derivatives in Peru has remained stable ${ }^{1}$. To obtain best results from this survey, the study was only focused on non-financial firms, without distinguishing between economic sectors. The questionnaire was mailed to the financial managers.

Taking into account the size and heterogeneity of the evaluated segment, a $90 \%$ confidence band was considered to determine the sampling dimension and to obtain a valid size of 65 observations necessary to represent statistically the chosen population. Then, the selection was performed by random sampling.

Among the 65 firms, the maximum average invoice amount was 3 billions dollars while the minimum was 42.75 millions. Most of the corporations (37) showed an invoice amount between 100 and 500 millions dollars; ten (10) of them showed an average invoice amount exceeding 500 million dollars.

1 Peru's Superintendencia de Banca y Seguros (Banking and Insurance Surveillance Agency) (www.sbs.gob.pe) inspects the transaction volumes of OTC bank market. 
From the total, 18 firms belonged to the manufacturing industry and twelve were from transportation, storage and communication sectors. Also, eleven companies worked in the wholesale and retail industry. Eight corporations belonged to the mining sector, and six were in the insurance and pension plan industry. The remaining ten firms were from other sectors.

If international exposure is considered as a motivation to handle derivatives, most companies were potentially affected by it since 40 of them exported during the year the study was conducted, and 60 of them imported. Defining the $5 \%$ of the average invoice amount of each firm as a standard, we find that the total amount of exports is greater in 16 firms; the total amount of imports is greater than this standard in 19 corporations, and the total amount of exports plus imports is greater in 33 firms. Only 5 out of 65 firms in the sample do not show any exports or imports.

\section{The survey}

The structured survey was designed based on the questionnaire that Wharton School of Business (University of Pennsylvania) applied in several countries to study and measure the activity of financial derivatives. In addition to the questions in the Wharton survey, some others related to the emerging countries reality were included. Likewise, several filter questions were included for certain subjects considered important such as the degree of qualification of the interviewees and their perception on the regulating institutions. The Likert scale was used with metric and dichotomous questions to analyse the variables and to evaluate precise conditions.

Internal consistency was estimated using Cronbach's Alpha coefficient, which had a value of 0.853 in a conducted pilot survey. The field work was run from May to July 2005. When the 31 items of the final survey were evaluated, the Cronbach's Alpha coefficient of 0.607 was obtained. In this estimation, the final sampling error was calculated in $9.75 \%$, which was considered acceptable for an investigation without previously known parameters.

Survey tabulation was carried out according to the type of question: metrics were derived to the statistical analysis, whereas dichotomous and categorical questions served to the descriptive analysis. Finally, filter questions were used to validate two items: (a) tendencies obtained in the survey, and (b) behaviour of respondents in the face of certain topics.

\section{Results of analysis}

In first place, preliminary results analysis was performed by means of survey tabulation. The objective was to gather results according to the topics of interest. Therefore, it allowed to make a comparative analysis and to contrast the tendencies of different variables.

Secondly, a multivariate analysis was conducted, focused on exploring the degree of dependency between the binary dependent variable that was "the use or non-use of financial derivatives" and 14 independent variables, which were determined empirically. In order to achieve it, two steps were carried out: (a) In the first step, factorial analysis was conducted to evaluate the influence of individual variables and their interactions in order to identify a reduced number of factors which could readily explained them; (b) a logistic regression was applied in order to analyze the influence of those factors on the dependent variable, making use of the stepwise procedure as a significant predictor in each of the regressions performed.

\section{RESULTS}

\section{Survey results}

According to the questionnaire results, $46 \%$ of the firms reported that interest rate risk affected them and $66 \%$ reported that foreign exchange risk also affected them. Nevertheless, concerning financial derivatives usage, only $33 \%$ of the firms confirmed using derivatives. At the same time, about frequency of usage, only $6 \%$ of the responding firms always used financial derivatives, $11 \%$ of the firms responded that they used them frequently, 20\% handled them sometimes, and $9 \%$ used them at some point in the past.

Firms handling derivatives were asked about the reasons why they did it. 38\% cited benefit perception; 
$35 \%$ answered because of the financial policy of the firm; $18 \%$ confirmed that derivative usage was a better strategy for financial managers; and $9 \%$ indicated that they were exploring this option. On the other hand, $44 \%$ of the surveyed companies confirmed that they did not use derivatives because of the financial policy of the corporation, and $44 \%$ answered they were exploring them.

Concerning training of the interviewed managers on financial derivatives, it was determined that only $20 \%$ were well versed in the topic, according to the filter questions related to the knowledge of derivatives market operation. Likewise, $62 \%$ of the total of firms did not have any training program on the subject nor use derivatives, whereas $18 \%$ had training programs but did not use derivatives. However, $80 \%$ of the companies with training, which is $16 \%$ of the total, used derivatives.

With respect to the main difficulties in developing the derivatives market, Figure 1 shows the difficulties in developing the derivative market in Peru. The main factor was the lack of knowledge with $42 \%$ of agreement. It follows the scarce supply in the local market, which amounted to $29 \%$ of the sample; the absence of an organized market accounted for $26 \%$; the difficulty in evaluating these instruments was $22 \%$, and the little clarity on tax regulations showed $20 \%$.

In the item Proposals submitted by the firms to favour the development of the derivatives market, the importance of knowledge of variables was highlighted since $65 \%$ of the corporations proposed spreading information about derivatives use as a mean to develop the market. Similarly, $65 \%$ of the firms considered that the development of an organized market was necessary, and $47 \%$ pointed the need to improve tax legislation.

The most important Issues that affect the use of financial derivative instruments considered by the responding firms were: (a) market risk (64.6\%); (b) evaluating and monitoring hedge results (53.8\%); (c) credibility in the operation (53.8\%); and (d) secondary market liquidity (38.5\%). Moreover, the results show that the use of advanced methods for risk management is minimum (only $15 \%$ used statistical measures), and an empirical management of the risk by means of monitoring market variables behaviour is generally practiced $(65 \%$ of the firms).

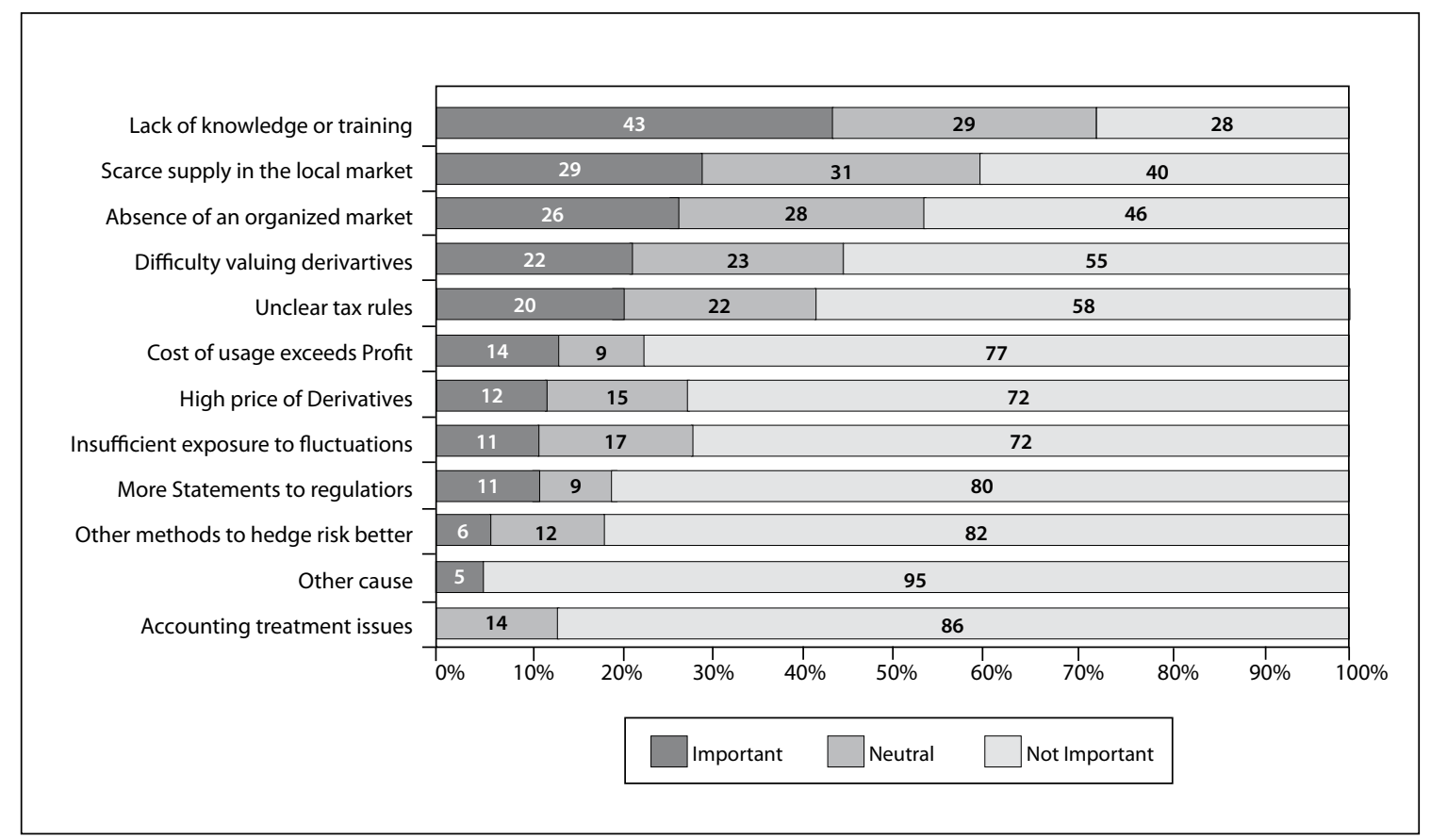

Figure 1. Main difficulties in developing the derivative market 
In reference to the relationship between the derivatives use and the stock market, it was found that $81 \%$ of the firms do not invest in financial instruments and almost $58 \%$ preferred to channel the use of derivatives through the banking market, which showed a preference by the OTC market.

\section{Multivariate statistical analysis}

As a first step in the multivariate statistical analysis, 14 variables were obtained based on the survey. With the purpose of verifying the appropriate application of the factorial analysis, the $\mathrm{KMO}^{2}$ index was calculated (resulting 0.642); to verify the effectiveness, the communalities were taken into careful account. Then, the main components were calculated, resulting that the first five variables, - which explained the $60.989 \%$ of the observed total variance of the 14 variables- presented eigenvalues major than the unit, satisfying the criterion to identify the number of factors.

Taking into account the correlations between factors and variables, these factors were interpreted and named appropriately. The first component comprises the variables concerning tax environment, existing regulations for accounting purposes and the credibility of the operation (which is understood as knowledge of the expected behavior of participants in the operation). This component factor was established as viability for completing the derivatives operation regarding the regulatory environment, identifying it as "Feasibility of derivatives use".

The second group of variables comprises the importance given to spreading the information, frequency of use, and stakeholders' reaction to the use of derivatives in the company. This group was associated with technical expertise on derivatives management and acceptance of its use, as a function of knowledge of the financial tool, and was identified as "Knowledge of market and training". The third component clusters the variables related to the perception of risk and also perception of market soundness as the base of trans-

2 The value of index KMO (Kaiser-Meyer-Olkin index) allows assuring a good factorial analysis. actions, and is accordingly identified as the "Notion of risk" in the use of derivatives.

Among the fourth group of variables, there are those related to the expected result of the operation, the perception about the legal scope, and the simplicity of operation with the instrument in market. These were identified as concepts related to the expected economic outcome, and to the legal and operating security of its achievement, leading to identify the fourth groups as the "Financial benefit" of the operation. The last component was greatly related to the perception on the variation of economic conditions that can be faced by using financial derivatives, and for that reason it was identified as "Interest rate and exchange rate volatility".

\section{Logistic regression}

In the last stage of the study, a logistic regression was performed to establish which of the factors had the greatest incidence on financial derivatives use in the evaluated firms. For that purpose, the selected dependent variable was "financial derivatives use" and the independent variables were the five identified factors in the factorial analysis. Regarding the independent variables, the resulting values of the factorial analysis were gathered for each one of the 65 observations in the survey, according to the recorded by the statistical software (SPSS) during the study. In this way, five independent variables were obtained corresponding to the five identified components. A stepwise procedure was used to ensure the best selection of variables; accordingly, the result was that the optimal variables for the model that presented significant relationship with the dependent variable were: (a) knowledge of the market and training, and (b) feasibility of use in the financial market. Table 2 details the logistic regression results.

It is important to emphasize that the "interest rate and exchange rate volatility" factor did not result as a relevant explanatory variable for derivatives usage, despite the fact that theoretically it is related to risk management. Nevertheless, the factors of subjective character (the feasibility of use and the knowledge of the market and training factors) were found as the 
Table 1. Main Components Based on the Oblimin Method

\begin{tabular}{|c|c|c|c|c|c|c|}
\hline \multirow[b]{2}{*}{ Factor } & \multicolumn{2}{|l|}{ Structure Matrix } & \multicolumn{3}{|c|}{ Componet } & \multirow[b]{2}{*}{5} \\
\hline & Variable & 1 & 2 & 3 & 4 & \\
\hline \multirow{3}{*}{ Feasibility of Use } & $\begin{array}{l}11 \text { C. Proposal: To adapt the current tax legislation to promote } \\
\text { is usage. }\end{array}$ & 0.796 & $(0.055)$ & $(0.087)$ & $(0.019)$ & $(0.184)$ \\
\hline & $\begin{array}{l}\text { 12A. Importance with respect to the derivatives use: } \\
\text { Accounting Treatment }\end{array}$ & 0.701 & 0.010 & $(0.293)$ & $(0.172)$ & 0.356 \\
\hline & $\begin{array}{l}\text { 12D. Importance with respect to the derivatives use: } \\
\text { Credibility in operations }\end{array}$ & 0.577 & $(0.376)$ & $(0.212)$ & $(0.220)$ & 0.086 \\
\hline \multirow{3}{*}{$\begin{array}{l}\text { Knowledge of } \\
\text { market and Training }\end{array}$} & $\begin{array}{l}11 \mathrm{~A} \text {. Proposal: To diffuse information about the instrument } \\
\text { derivatives use. }\end{array}$ & 0.296 & $(0.686)$ & 0.003 & 0.246 & 0.069 \\
\hline & 8. How long the firm uses derivatives financial instruments & 0.143 & 0.678 & 0.001 & 0.011 & 0.156 \\
\hline & $\begin{array}{l}\text { 12E. Importance with respect to derivatives use: Reaction of } \\
\text { analyst/invertors (interest in participation) }\end{array}$ & 0.105 & $(0.537)$ & 0.092 & $(0.377)$ & $(0.168)$ \\
\hline \multirow{3}{*}{ Notion of Risk } & 12C. Importance with respect to derivatives use: Market Risk & 0.078 & 0.074 & $(0.742)$ & 0.169 & $(0.008)$ \\
\hline & 12B. Importance with respect to derivatives use: Credit Risk & 0.417 & $(0.047)$ & $(0.631)$ & $(0.288)$ & 0.303 \\
\hline & $\begin{array}{l}\text { 11B. Proposal: To Develop formal market transaction of } \\
\text { derivatives instruments }\end{array}$ & 0.343 & $(0.110)$ & $(0.504)$ & $(0.091)$ & $(0.326)$ \\
\hline \multirow{3}{*}{ Financial Benefits } & $\begin{array}{l}\text { 12G. Importance with respect to derivatives use: Evaluation } \\
\text { and requirements of the hedge results }\end{array}$ & 0.060 & 0.002 & $(0.025)$ & (0.809) & 0.016 \\
\hline & $\begin{array}{l}12 \mathrm{~F} \text {. Importance with respect to derivatives use: Legal } \\
\text { requirements }\end{array}$ & 0.566 & 0.132 & 0.012 & $(0.671)$ & 0.268 \\
\hline & $\begin{array}{l}12 \mathrm{H} \text {. Importance with respect to derivatives use: Secondary } \\
\text { market liquidity }\end{array}$ & 0.128 & $(0.265)$ & $(0.550)$ & $(0.550)$ & 0.129 \\
\hline \multirow{2}{*}{$\begin{array}{l}\text { Interest Rate and } \\
\text { Exchange Rate } \\
\text { Volatility }\end{array}$} & $\begin{array}{l}1 \mathrm{~A} . \text { With respect to interest rate fluctuation, its unexpected } \\
\text { variation would affect the operations significantly? }\end{array}$ & $(0.032)$ & 0.212 & $(0.056)$ & (0.048) & 0.853 \\
\hline & $\begin{array}{l}\text { 1B. With respect to the exchange rate fluctuation, } \\
\text { an unexpected variation would affect the operation } \\
\text { significantly? }\end{array}$ & 0.266 & $(0.323)$ & 0.455 & 0.016 & 0.484 \\
\hline
\end{tabular}

Extraction Method: Principal Component Analysis.

Rotation Method: Oblimin with Kaiser Normalization

Table 2. Results of the Logistic Regression

\begin{tabular}{lccrrrrr} 
& & & & & \multicolumn{2}{c}{$95 \%$ C.I. for EXP(B) } \\
\hline & B & S. E. & Wald & Sig. & Exp (B) & Lower & Upper \\
\hline 1. Feasibility of use & 0,679 & 0.350 & 3.760 & 0.052 & 1.972 & 0.993 & 3.917 \\
2. Knowledge of market and Training & 1.713 & 0.478 & 12.848 & 0.000 & 5.548 & 2.174 & 14.157 \\
Constant & -0.896 & 0.334 & 7.180 & 0.007 & 0.408 & & \\
\hline
\end{tabular}


most significant ones (see Table 2). As a consequence, propensity in the use with respect to the non use of derivatives is greater when the feasibility of use factor $(\operatorname{Exp}(B)=1.972)$ and the knowledge of market and formation factor $(\operatorname{Exp}(B)=5.548)$ increase.

\section{Comparison with similar studies}

A study about the use of derivative instruments in Argentinean non financial firms was conducted by Tappatá, Levy Yevaty and Jakoniuk (2000). From a similar survey to the applied in this study, some factors were identified by inference, while statistical methods were used in our study to reach similar conclusions. In this sense, the factors affecting the development of derivatives markets and identified by them were: (a) few information owned by the risk managers about derivatives; (b) scarce supply of them in the local market; and, (c) agency problems in risk management practice. These were related to the ones found in our study: (a) knowledge of market and training; (b) feasibility of use; (c) notion of risk and financial benefit, respectively. This study is perhaps more comparable to our work since the subject is the same, and it is also applied in a Latin American country.

Another study conducted on Spanish firms is also a reference because it also applies the factors we employ. Azofra \& Diez (2001) found factors affecting the use of exchange risk hedging by associating them with measurable characteristics and then conducting a regression with those characteristics as independent variables. In our study, those factors were identified by researching from the results of other less general variables. The factors they investigated were: (a) existence of economies of scale in information regarding the use of derivatives; (b) existence of economies of scale in transactions regarding the use of derivatives; (c) agency problems; (d) financial problems; and, (e) degree of economic exposure to the foreign exchange risk. The factors were clearly related with the ones found in our study: (a) knowledge of market and training; (b) feasibility of use; (c) financial benefit; (d) notion of risk; (e) interest rate and exchange rate volatility, respectively.

\section{CONCLUSIONS}

In most emerging markets, large firms do not practice a generalized use of derivatives. In this sense, there is a low percentage of firms and a small traded volume. Although the firms are aware of interest rate and foreign exchange risks, they do not carry out a formal risk management. Furthermore, those risks are not the most influential factor in the use of the derivatives according to the study results.

In fact, the issue that influences the most in derivatives use is the degree of market knowledge and the level of training on these financial instruments. This shows the importance of disclosure and training as alternatives to prompt the development of these instruments. However, training in financial derivatives and hedges is currently limited, and its deficiency is considered by the firms as the main obstacle to achieve the development of this market.

The importance of regulations - tax, legal and accounting issues - might be realized attending to its effects on feasibility of derivatives use. About regulation on derivatives use, the main problem is that the Peruvian tax system does not count with a proper set of official rules (internal revenues service), which extremely hinders the firms annual statements of taxes and the accounting registry. Consequently, it is necessary to prioritize stimulation for the development and enhancement of regulation on financial derivatives use.

Moreover, it was found that firms prefer to participate through banking market (over the counter) when using financial derivatives. This situation can be used as a guide to initiate the development of derivatives market since study results indicate that there is no great interest in using organized markets of derivatives; this is related to the lack of use of bonds and shares in cooperatives' investments. As a result, it is also necessary to encourage development of the capital market in order to advance derivatives market.

Finally, an interesting issue for further research would be to conduct the same studies in other Latin American countries, thus incorporating a regional comparison. 


\section{REFERENCES}

Alkeback, P., \& Hagelin, N. (1999) Derivative usage by nonfinancial firms in Sweden with an international comparison. Journal of International Financial Management \& Accounting, 10(2), 105.

Azofra, V., \& Diez, J. M. (2001). La cobertura corporativa del riesgo de cambio en las empresas no financieras españolas (Working Paper 15/01). Universidad de Valladolid.

Berkman, H., \& Bradbury, M. (1996). Empirical Evidence on the Corporate Use of Derivatives. Financial Management, 25, 5-13.

Block, S., \& Gallagher, T. (1986). The Use of Interest Rate Futures and Options by Corporate Financial Managers. Financial Management, 15, 73-78.

Bodnar, G. M., Hayt, G. G., Marston, R. C., \& Smithson, C. W. (1995): Wharton Survey of Derivatives Usage by U.S. Non-Financial Firms. Financial Management, 24(2), 1995, 104-114.

Bodnar, G. M., \& Marston, R. C. (1996) Survey of Derivatives Usage by U.S. Non-Financial Firms. Philadelphia, PA: Wharton School of the University of Pennsylvania.

Bodnar, G. M., Hayt, G., \& Marston, R. (1998) Wharton Survey of Derivatives Usage by U.S. Non-Financial Firms. Financial Management, 27(4), 70-91.

Bodnar, G., \& Gebhardt, G., (1999) Derivatives usage in risk management by US and German non-financial firms: A comparative survey. Journal of International Financial Management \& Accounting. 10(3), 153.

Bodnar, O. K., Hayt G. G., \& Marston R. C.. (1996). Wharton Survey of Derivatives Usage by U.S. Non-financial Firms. Financial Management, 25(Winter), 113-133.

Borokhovich, K., Brunarski, K., Crutchley, C., \& Simkins, B. (2004). Board composition and Corporate Use of Interest Rate Derivatives. Journal of Financial Research, 27(2), 199-126.

Geczy, C., Minton, B., \& Schrand, C. (1997). Why Do Firms Use Currency Derivatives? Journal of Finance, 52, 13231354.
Joseph, N., \& Hewins, R. (1997). The motives for corporate hedging among UK multinationals. International Journal of Finance and Economics, 2, 151-171.

Mian, S. (1996). Evidence on Corporate Hedging Policy. Journal of Financial and Quantitative Analysis 31, 419-439.

Nance, D., Smith, C. W., \& Smithson, C. (1993). On the Determinants of Corporate Hedging. Journal of Finance, 48, 267-284.

Nguyen, H., \& Faff, R. (2002). On the determinants of derivative usage by Australian companies. Australian Journal of Management. 27(1), 1.

Prevost, A., Rose, L., \& Miller, G. (2000). Derivatives usage and financial risk management in large and small economies: A comparative analysis. Journal of Business Finance \& Accounting. 27(5/6), 733.

Rivas-Chavez, A. E., (2003). Three essays on the use of financial derivatives by Latin American banks in Brazil, Chile and Mexico. Austin, TX:The University of Texas - Pan American.

Samant, A. (1996). An Empirical Study of Interest Rate Swap Usage by Nonfinancial Corporate Business. Journal of Financial Services Research, 10, 43-57.

Tappatá, M., E., Levy Yevaty, E., \& Jakoniuk, G. (October, 2000). El Uso de Instrumentos Derivados en Empresas no Financieras: El caso de Argentina (Working Paper). Universidad Torcuato di Tella.

Treasury Management Association. (1996). Results of the 1996 Survey Questionnaire on Disclosure of Accounting Policies and Market Risk Relative to Derivative Financial and Commodity Instruments. Author: October 1996.

Yanagida, M., \& Inui, K. (1995). Survey of Derivatives Usage among Non-Financial Japanese Firms (Working Paper). NLI Research. 


\section{APPENDIX}

\section{Survey to determine the level of financial derivatives employed}

Name of the firm:

Name of Financial Manager:

Telephone number / e-mail:

RUC: (Tax Contribution registry number)

\section{EXCHANGE AND INTEREST RATE EXPOSURE}

1. Regarding the exchange rate and interest rate fluctuation, would an unexpected variation affect your operations significantly?

\begin{tabular}{|c|c|c|c|}
\hline & & Exchange Rate & Interest Rate \\
\hline 5 & Extremely & 6 & 2 \\
\hline 4 & Do affect & 37 & 28 \\
\hline 3 & Moderately & 15 & 23 \\
\hline 2 & Not too much & 6 & 9 \\
\hline 1 & Do not affect & 1 & 3 \\
\hline
\end{tabular}

2. Do you think that exchange rate/ interest rate will vary?

\begin{tabular}{|c|c|c|c|}
\hline & & Exchange Rate & Interest Rate \\
\hline 5 & At Short term & 7 & 24 \\
\hline 3 & At Medium Term & 43 & 31 \\
\hline 1 & At Long term & 15 & 10 \\
\hline
\end{tabular}

\section{DIFFUSION OF USE OF DERIVATIVE INSTRUMENTS}

3. Do you know the interest rate of derivative products that SBS (Peru's Banking and Insurance Surveillance Agency) publishes in its web portal?

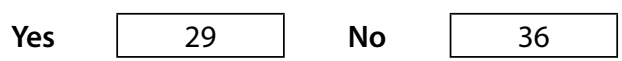

\section{USE OF DERIVATIVE INSTRUMENTS}

4. Do you think that in the financial or risk management area of your firm exists a proper training in derivatives products?

Proper training Not proper training 35


5. If training exists or existed? Where did this training take place and how many people of the finance department participated?

\begin{tabular}{|l|r|}
\hline \multicolumn{1}{|c|}{ Training exists } & \multicolumn{1}{c|}{} \\
\hline Everybody & 5 \\
\hline More than $50 \%$ & 11 \\
\hline $25 \%$ to $50 \%$ & 6 \\
\hline Less than $25 \%$ & 14 \\
\hline No one & 25 \\
\hline No answer & \\
\hline
\end{tabular}

6. How many people work in the finance or risk management department?

$\begin{array}{cc}3 \text { or less } & 26 \\ 4 \text { to } 5 & 20 \\ \text { Beyond } 5 & 19\end{array}$

IV. USE OF DERIVATIVE INSTRUMENTS

7. Does your firm use derivative instruments?

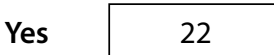

And why?

\begin{tabular}{|l|r|}
\hline It is the financial policy of the firm & 12 \\
\hline It is the best strategy considered by the financial manager & 6 \\
\hline We are exploring the use of derivatives & 3 \\
\hline For its benefits & 13 \\
\hline
\end{tabular}

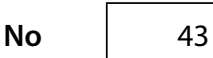

\begin{tabular}{|l|r|}
\hline It is the financial policy of the firm & 18 \\
\hline It is the best strategy considered by the financial manager & 3 \\
\hline We are exploring the use of derivatives & 16 \\
\hline For its benefits & 3 \\
\hline
\end{tabular}


8. How often does your firm use financial derivative instruments?

\begin{tabular}{|l|r|}
\hline Always & 4 \\
\hline Frequently & 7 \\
\hline Sometimes & 13 \\
\hline Not use & 6 \\
\hline In the past & 32 \\
\hline Not answer & 3 \\
\hline
\end{tabular}

9. If you used it in the past, what was your experience? :

\begin{tabular}{|l|r|}
\hline Positive & 19 \\
\hline Neutral & 7 \\
\hline Negative & 2 \\
\hline Without experience & 26 \\
\hline Not answer & 10 \\
\hline
\end{tabular}

10. Please indicate the five most important problems to develop derivatives market in Peru you consider: Please rank: (1- Least important 5 - Most important)

Problems:

\begin{tabular}{|c|c|c|c|c|c|c|}
\hline & & & & & & \\
\hline & & 1 & 2 & 3 & 4 & 5 \\
\hline A & Insufficient exposure to financial fluctuations (interest rates, exchange rates). & 6 & 6 & 5 & 4 & 3 \\
\hline B & Exposure is more effectively managed by others means. & 5 & 2 & 6 & 2 & 2 \\
\hline $\mathbf{C}$ & Lack of knowledge / training about the use of derivative instruments. & 8 & 11 & 8 & 10 & 18 \\
\hline D & Absence of an organized market. & 4 & 10 & 7 & 10 & 7 \\
\hline $\mathbf{E}$ & Scarce supply of these instruments in the local market. & 8 & 6 & 14 & 6 & 12 \\
\hline $\mathbf{F}$ & High prices of derivatives. & 8 & 6 & 4 & 4 & 3 \\
\hline G & Costs of establishing and maintaining a derivatives program exceed the expected profits. & 4 & 4 & 2 & 5 & 4 \\
\hline $\mathbf{H}$ & Difficulty valuing derivatives. & 4 & 6 & 9 & 9 & 5 \\
\hline $\mathbf{I}$ & Its usage implies additional statements to the tax administration and other regulators. & 3 & 4 & 2 & 5 & 2 \\
\hline J & Accounting treatment issues. & 3 & 5 & 4 & 0 & 0 \\
\hline $\mathbf{K}$ & Unclear tax rules & 10 & 7 & 6 & 8 & 5 \\
\hline $\mathbf{L}$ & Other (specify). & 0 & 0 & 0 & 2 & 1 \\
\hline
\end{tabular}


11. Which are, in your opinion, the proposals to develop the derivatives market in Peru? Please rank: (1- Least important 5-Most important)

\begin{tabular}{|c|c|c|c|c|c|c|}
\hline & & & & & & \\
\hline & & 1 & 2 & 3 & 4 & 5 \\
\hline A & Diffuse information about use of derivative instruments. & 8 & 0 & 14 & 14 & 29 \\
\hline B & Development of a transactional formal market with derivative instruments & 5 & 5 & 13 & 21 & 21 \\
\hline $\mathbf{C}$ & Adequate the current tax legislation in order to promote its usage. & 12 & 1 & 21 & 19 & 12 \\
\hline D & Other proposals : Specify & 0 & 0 & 0 & 0 & 1 \\
\hline
\end{tabular}

12. Indicate your degree of concern about the following issues with respect to derivatives use.

Please rank: (1- Least important 5-Most important)

\begin{tabular}{|c|c|c|c|c|c|c|}
\hline & \multirow{3}{*}{$\begin{array}{r}1 \\
23\end{array}$} & \multirow{3}{*}{$\begin{array}{r}2 \\
10\end{array}$} & \multirow{3}{*}{$\begin{array}{r}3 \\
20\end{array}$} & \multirow{3}{*}{$\begin{array}{l}4 \\
7\end{array}$} & \multirow{3}{*}{$\begin{array}{l}5 \\
5\end{array}$} \\
\hline & & & & & & \\
\hline A & Accounting treatment & & & & & \\
\hline B & Credit Risk & 17 & 16 & 12 & 9 & 11 \\
\hline C & Market Risk & 5 & 8 & 10 & 20 & 22 \\
\hline D & Credibility of the operation & 14 & 9 & 7 & 16 & 19 \\
\hline E & Reaction (interest in participation) by investors or analysts & 23 & 12 & 11 & 11 & 8 \\
\hline $\mathbf{F}$ & Legal Requirements & 23 & 11 & 19 & 9 & 3 \\
\hline G & Monitoring and evaluating hedge results & 15 & 3 & 12 & 23 & 12 \\
\hline H & Secondary market liquidity. & 23 & 8 & 9 & 16 & 9 \\
\hline
\end{tabular}

13. Does your firm use any statistical measurement to calculate the risk of its derivatives portfolio (example: "value at risk")?

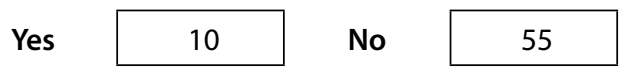

If your answer was Yes, which is the method used?

14. How do you evaluate the risks in the firm?

\begin{tabular}{|l|c|}
\hline With numerical / computational models & 19 \\
\hline With market indicators & 40 \\
\hline It is not necessary to evaluate risk & 6 \\
\hline
\end{tabular}

15. Does your firm invest in the stock exchange?

\begin{tabular}{|l|r|}
\hline Frequently & 7 \\
\hline Occasionally & 5 \\
\hline Not invest in Stock Exchange & 53 \\
\hline
\end{tabular}


16. Which of the following statements would you chose to obtain a financial derivative instrument?

\begin{tabular}{|l|r|}
\hline Organized markets (similar to Lima Stock Exchange or CBOE) & 20 \\
\hline "Tailor-made" products offered by Private Banking & 32 \\
\hline Both & 3 \\
\hline Not answer & 10 \\
\hline
\end{tabular}

Comment the reason of your answer: 